\title{
Measurement of 3-methylhistidine in spot urine from HIV-infected persons: an alternative screening method for muscle protein degradation to serum $\mathbf{C K}$ AC Venhoff1', E Bissé2 ${ }^{2}$ T Epting ${ }^{2}$, J Thoden ${ }^{1}$, UA Walker ${ }^{1}$ and N Venhoff*1
}

Address: ${ }^{1}$ University Hospital Freiburg/Dept. Rheumatology and Clinical Immunology, Freiburg, Germany and 2University Hospital Freiburg/ Dept. of Clinical Chemistry, Freiburg, Germany

* Corresponding author

from Ninth International Congress on Drug Therapy in HIV Infection

Glasgow, UK. 9-13 November 2008

Published: 10 November 2008

Journal of the International AIDS Society 2008, I I (SuppI I):P2 I0 doi:I0.II86/I758-2652-I I-SI-P2IO

This abstract is available from: http://www.jiasociety.org/content/II/SI/P210

(C) 2008 Venhoff et al; licensee BioMed Central Ltd.

\section{Purpose of the study}

3-methylhistidine (3-MH) acts as an in vivo label of the rate of myofibrillar protein breakdown. The aim of this study was to evaluate 3-MH measurement in spot urine as a simple screening method for muscle protein degradation in HIV-infected persons compared to creatine kinase (CK) measurement in blood.

\section{Methods}

We prospectively measured serum creatinine $(\mathrm{mg} / \mathrm{dl})$ and serum CK $(\mathrm{U} / \mathrm{L})$ and $3-\mathrm{MH}(\mu \mathrm{mol} / \mathrm{L})$ in spot urine from 162 HIV-positive subjects at each visit. 3-MH was determined by HPLC after derivatization with fluorescamine.

\section{Summary of results}

162 HIV-positive subjects were screened; two patients were excluded because of renal dysfunction. $160 \mathrm{HIV}$-positive patients (101 male) entered the study and a total of 397 visits were analysed. The median age at all visits was 44 years (range 21-75). Body mass index (BMI) was 24.8 \pm 5.1 (men $24.93 \pm 0.29$, women $24.5 \pm 0.48$ ). Patients were without antiretroviral treatment (ART) at $24 \%$ of visits and had an undetectable serum HIV load ( $<50$ copies/ $\mathrm{ml}$ ) at $50 \%$ of visits. The median CD4 count was 437 cells/ $\mu \mathrm{l}$ (SD 205.1). CK, creatinine and 3-MH did not correlate with the number of visits.

A positive correlation with the BMI was found for CK and creatinine, but not for 3-MH. Compared to men, women had significantly lower levels of 3-MH $(195.5 \pm 10.5$ vs. $252.2 \pm 9.6, \mathrm{p}=0.0002)$, creatinine $(0.68 \pm 0.01$ vs. 0.85 $\pm 0.01, \mathrm{p}<0.0001)$ and $\mathrm{CK}(106 \pm 7.6$ vs. $156.9 \pm 8.2, \mathrm{p}<$ $0.0001)$. Patients with CK levels above $300 \mathrm{U} / \mathrm{L}(\mathrm{n}=31)$ had significantly higher 3-MH levels than patients with CK below $50 \mathrm{U} / \mathrm{L}(\mathrm{n}=41)(\mathrm{p}=0.037)$. Otherwise there was no correlation between CK and 3-MH. ART in general, and zidovudine (177 visits) and tenofovir (90 visits) in particular, did not influence the levels of $\mathrm{CK}$, creatinine and 3-MH.

\section{Conclusion}

In conclusion, measurement of 3-MH on spot urine samples is not useful for assessing changes in muscular protein degradation. A meat-free diet, 24-hour urine collection and refraining from physical activity might reduce confounding factors of 3-MH secretion. 